\title{
Nexus between Infrastructure and Tourism Development
}

\author{
Sourav Kumar Das
}

$\mathrm{PhD}$ Candidate, Lecturer, Department of Economics, Lalbaba College, Belur, Howrah, India

\section{Kishor Naskar}

PhD Candidate, Assistant Professor, Department of Economics, Budge Budge College, Kolkata, India

\begin{abstract}
Infrastructure is nothing but the pre-requisites for economic development. It is not the engine but the wheels of economic development. Since the onset of economic crisis, followed by economic reforms, the importance of infrastructure development has been emphasized through policy, pronouncements, higher budgetary allocation of funds, formation of infrastructure development, financing corporation, huge private intervention in infrastructure development, both Indian and foreign. It opens out a region by providing an access to its tourist places. In its absence, the resource potential for tourism i.e. attractions and amenities, can't be of any benefit. We cannot talk about the planning of tourism in an area without organizing its transport system. In addition to the common infrastructure tourism development requires special infrastructures, which growing importance to India and foreign tourists in recent year in India has already made a place on the world's tourism map because of its great potential to attract tourists to the diversity of its tourist sites spread all over the country. Considering the potentialities of these diversities in attracting tourists, the infrastructure requirement for their development must be assessed in terms of its availability and future needs. By making available sufficient funds through public and private sector involvement and engaging both Indian and foreign experts, tourism could be developed and made attractive without harming the green environment of the surrounding areas. This paper tries to investigate the significance of infrastructure as a factor of tourism development. The study also reveals the impact of tourism on the greater need for development of transport network. This paper uses the panel data estimation techniques and finds that the infrastructure has been contributing positively to tourist arrivals, particularly from India and abroad. Moreover, tourism infrastructure, relative prices, distance and income in the origin countries are important ingredients in their own respect in the tourism demand equation. Direct and indirect forms of government intervention might be necessary to ensure the protection of natural resources and the equitable distribution of economic benefits from tourism development. At the same time, incentives must be provided to the private sector to encourage financial investment in development activity that adheres to the principles of sustainable tourism. Encouraging cooperation and collaboration among different actors, as well as public-private sector partnerships, should assist in reducing potential and actual conflicts of interests and values. In addition, these actions should facilitate the more efficient use of resources and capabilities to achieve the destination's economic objectives.
\end{abstract}

Keywords: infrastructure, tourism development, panel data analysis, indian tourism.

JEL Classification: L83, H54, C23.

(C) The Authors, 2018. This article is published with open access at Sumy State University.

\section{Introduction}

Income in the country of origin, the cost of travel, relative prices, exchange rates and tourism infrastructure are among the most prominent determinants of tourism flows in the existing empirical literature. A number of authors, including Gunn (1988) and Inskeep (1991) have cited the infrastructural base of a country as a potential determinant of the attractiveness of a tourism destination. (Khadaroo et al., 2007) investigated the significance of transport infrastructure as a factor in destination development, showing it to be a part of classical demand for international tourism functions. An application involving the island of Mauritius presented whereby total tourist arrivals were modelled. The findings showed that tourists from Europe/America and Asia were particularly sensitive to the island's transport infrastructure. Those from Europe/America are also sensitive to its nontransport infrastructure. Smith (1994), Crouch and Ritchie (1999) developed a good theoretical model to explain the role of service infrastructure in tourism development. Kaul (1985) also examined the importance of infrastructure more specifically, transport is an essential component of successful tourism development. The Tourism Task Force (2003) of Australia reported that infrastructure play an important role in tourist consideration. The transport system should be very smooth for connecting tourism-generating regions 
to tourism-destination regions as well as providing transport within the tourism destination (Prideaux, 2000). In fact, Mo, Howard and Havitz (1993), using survey methodology, find that tourists prefer to travel to countries that have the same infrastructures as in their home country. So different types of infrastructure, as well as income of tourists, distance, and relative prices are important ingredients in their own respect in the tourism demand equation. Infrastructure forms an integral part of the tourism package. For instance, road infrastructure enhances accessibility of tourists to different parts of the destination country while sound airport infrastructure ensures that tourists experience a comfortable transition from the plane into the borders of the destination country and vice versa. As such communication infrastructure allows quick and cheap communication between the origin and destination country as well as provides maximum information about the destination thereby reducing uncertainty, fear and asymmetric information. Other infrastructure such as waste water and energy among others are also believed to result in more reliable services and thus enhance the attractiveness of the destination.Tourist infrastructure forms a vital basis for tourism development. It is a component of regional touristic product. It envelops a variety of essential amenities and supplementary facilities. The basic facilities for tourism have to be provided at three nodal points:

$>$ those required at the tourist points,

$>$ continued enroute along the journey upto the destination area, and

$>$ at the destination areas.

The domestic tourism, if properly developed, will itself function as infrastructure for external tourism. The requirements for domestic tourism have to the assessed and plans chalked out for meeting these requirements and this will be the first step towards the infrastructure development. The creation of these facilities will also contribute towards economic uplift of the area by generating relative activities by private enterprises. Future increase in tourist flow mainly depends on integrated growth and development of areas of tourist interest. It becomes necessary to see that the development plan and design are in harmony with the overall objective of promoting a unique character making the best use of natural features.

The operation of tourism facilities, services and amenities are often dependent on a number of travel infrastructure networks. These networks may include transportation, water supply, energy/power, waste disposal and telecommunications. There is some ambivalence towards the view that all the infrastructure networks must be in place before tourism activity can take place. The reason is that in some developing countries, resort developments appear to function adequately and to the satisfaction of their clients without full infrastructure systems being in place. In the case of some forms of tourism development, the lack of a complete network of modern highways may be advantageous in that since the absence of the network acts as a deterrent to the penetration of mass tourism to environmentally sensitive areas. For some isolated tourism development, such as independent and sometimes remote integrated resorts, all the basic operating infrastructure systems are incorporated in the overall design, while in regard to infrastructure the resort may be self-sufficient without needing any connection to any more general urban or regional systems. The problem with the independent resort unit may be that it solves satisfactorily all its infrastructure needs within its own territory, but by doing so, may "export" some of the water supply and waste disposal problems to other areas.

The most usual case in tourism development is for infrastructure development to precede the completion of the tourism facilities. This may mean that the installation of the infrastructure becomes a public sector responsibility, with some escalation of the cost for development as a contribution to the overall costs of tourism development. A rationale for the infrastructure services being a public sector responsibility includes consideration of the following factors:

$>$ the network of services is most likely available to both tourists and residents of the area;

$>$ achievement of consistency in standards is desirable;

$>$ the construction of an integrated system may facilitate non-tourism development within the region;

$>$ the network will facilitate development that contributes to the economic welfare of the resort or region;

$>$ the network will need to be maintained by public agencies to ensure that prescribed standards are met.

\section{Entities financing tourism infrastructure}

The financing of infrastructure is most important. Though government takes the initiative to develop an environment of tourism in the remote magnificent place, there is private sector also to carry forward the good initiatives of government. The infrastructure can be classified into three broad categories:

Commercial: hotels, nutrition, tourist arrival servicing. 
Public: roads, communal, trails.

Mixed (Public-Commercial): information, accompanying.

The commercial entities like hotels or restaurants create and exploit objects for servicing their clients (tourists). Public entities (self-government units and state entities) develop techno-social infrastructure not only for tourists servicing but also, or rather first of all, for creation the conditions for local regions and regions development minding society (including tourists) and economy (including tourism economy entities).

Attention should be paid to the necessity of co-operation between commercial and public entities. Involvement of commercial entities in taking up public financed activities for creation infrastructure is possible, e.g. through public private partnership (Zysnarski, J., 2003).

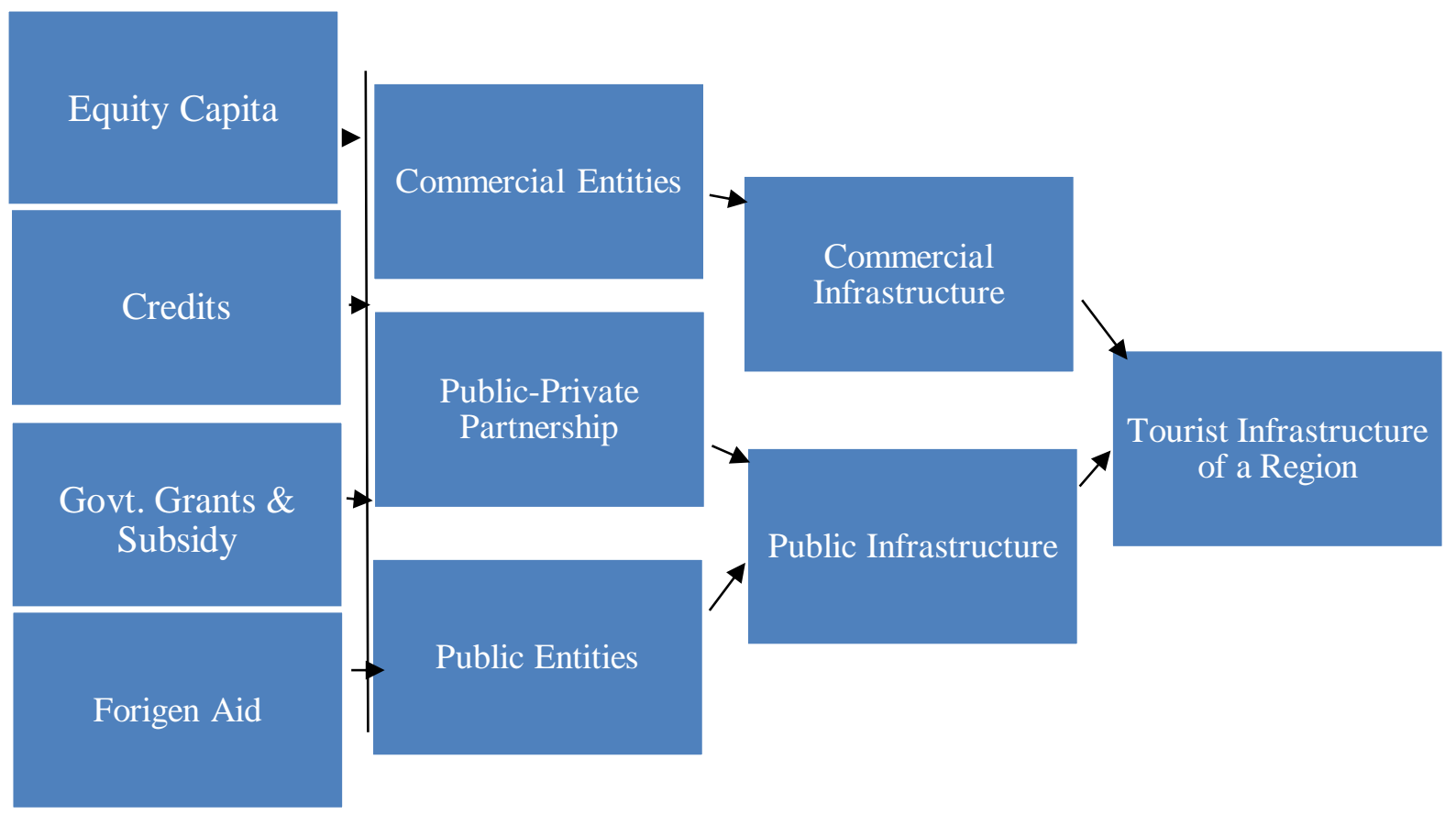

Figure 1. Entities financing to create tourist infrastructure

The flow chart suggested that the both commercial entities (private sector) and public entities (state or local government bodies) are involved in creation and financing the tourism infrastructure. They create the tourism infrastructure simultaneously having the possibility of taking up joint ventures through the public-private partnership. Activities in this field are directed at the public infrastructure (e.g. access roads to hotels) or co-create tourist function of the region, namely local infrastructure in tourist cities (pavements, promenades, piers, tourist information).

\section{Time series analysis in the context of India}

Tourism is currently an important segment of the Indian economy and it has become an instrument for the promotion of handicrafts, arts and cultural heritage of the country. The tourism industry in India has been declared a priority sector for foreign investment. The infrastructure for tourism in India comprises not only onsite facilities such as hotels, restaurants etc., but also all forms of transport and communication infrastructure and basic amenities. Several agencies therefore need to be involved. The Ministry of Tourism of India is in the process of creation of a new tourism policy that aims to achieve necessary linkages and synergies in the policies and programs of concerned agencies by establishing effective coordination mechanisms at the central, state and district levels. The focus of the policy will be to develop tourism as a common endeavour by all agencies concerned at the central and state levels, and it will also include public sector undertakings and the private sector. Therefore, the government has launched many activities focused on infrastructure and human resource development in support of the tourism industry, which will be completed by various agencies involved.

The Ministry of Tourism compiles monthly estimates of Foreign Tourist Arrivals (FTAs) on the basis of nationality-wise, port-wise data received from the Bureau of Immigration (BOI) and Foreign Exchange Earnings (FEEs) from tourism on the basis of data available from the Reserve Bank of India. The FTAs in India continued to grow from 1.28 million in 1981 to 1.68 million in 1991, 2.54 million in 2001, to reach 8 million in 2015. 
During 2014, FTAs in India registered a double digit growth of $10.2 \%$ over 2013. It becomes single digit for the year 2015. The Compound Annual Growth Rate (CAGR) in FTAs in India was 8.9\% during 2001-2014. The corresponding table gives the detailed number of FTAs in India for the years from 2000 to 2015 along with the corresponding growth rate over the previous year.

Table 1. Foreign Tourist Arrivals (FTAs) in India (2000-2015)

\begin{tabular}{|c|c|c|}
\hline Year & FTAs in India & Annual Growth (\%) \\
\hline 2000 & 2649378 & 6.7 \\
\hline 2001 & 2537282 & -4.2 \\
\hline 2002 & 2384364 & -6.0 \\
\hline 2003 & 2726214 & 14.3 \\
\hline 2004 & 3457477 & 26.8 \\
\hline 2005 & 3918610 & 13.3 \\
\hline 2006 & 4447167 & 13.5 \\
\hline 2007 & 5081504 & 14.3 \\
\hline 2008 & 5282603 & 4.0 \\
\hline 2009 & 5167699 & -2.2 \\
\hline 2010 & 5775692 & 11.8 \\
\hline 2011 & 6309222 & 9.2 \\
\hline 2012 & 6577745 & 4.3 \\
\hline 2013 & 6967601 & 5.9 \\
\hline 2014 & 7679099 & 10.2 \\
\hline 2015 & $80,27,133$ & 4.5 \\
\hline
\end{tabular}

Source: The Bureau of Immigration, India.

The growth in FTAs in India during the 80-th and 90-th did not follow any consistent pattern. A double digit positive growth was notices in 2003-2007, 2010-2014, though there was a negative growth in 2001-2002 and 2009. Now let describe this more elaborately.

Table 2. Foreign Tourist Arrivals (FTAs) from Tourism in India during December 2015 and comparative figures of 2014 and 2013

\begin{tabular}{|c|c|c|c|c|c|}
\hline \multirow{2}{*}{ Month } & \multicolumn{3}{|c|}{ Foreign Tourist Arrivals (Nos.) } & \multicolumn{2}{c|}{ Percentage Change } \\
\cline { 2 - 6 } & 2013 & 2014 & 2015 & $2014 / 13$ & $2015 / 14$ \\
\hline January & $7,20,321$ & $7,57,786$ & $7,90,854$ & $5.2 \%$ & $4.4 \%$ \\
\hline February & $6,88,569$ & $7,55,678$ & $7,61,007$ & $9.7 \%$ & $0.7 \%$ \\
\hline March & $6,39,530$ & $6,90,441$ & $7,29,154$ & $8.0 \%$ & $5.6 \%$ \\
\hline April & $4,50,580$ & $5,35,321$ & $5,41,551$ & $18.8 \%$ & $1.2 \%$ \\
\hline May & $4,17,453$ & $4,65,043$ & $5,09,869$ & $11.4 \%$ & $9.6 \%$ \\
\hline June & $4,51,223$ & $5,02,028$ & $5,12,341$ & $11.3 \%$ & $2.1 \%$ \\
\hline July & $5,06,427$ & $5,68,871$ & $6,28,323$ & $12.3 \%$ & $10.5 \%$ \\
\hline August & $4,86,338$ & $5,75,750$ & $5,99,478$ & $18.4 \%$ & $4.1 \%$ \\
\hline September & $4,53,561$ & $5,09,142$ & $5,42,600$ & $12.3 \%$ & $6.6 \%$ \\
\hline October & $5,98,095$ & $6,68,398$ & $6,83,286$ & $11.8 \%$ & $2.2 \%$ \\
\hline November & $7,33,923$ & $7,65,497$ & $8,15,947$ & $4.3 \%$ & $6.6 \%$ \\
\hline December & $8,21,581$ & $8,85,144$ & $9,12,723$ & $7.7 \%$ & $3.1 \%$ \\
\hline Total & $69,67,601$ & $76,79,099$ & $80,27,133$ & $10.2 \%$ & $4.5 \%$ \\
\hline
\end{tabular}

Source: The Bureau of Immigration, India.

From the data it is pretty clear to us that the tourist arrival to India has increased over the year. There is a positive percentage change in FTAs with respect to 2013. Though the change in percentage is quite low for the year 2015, yet it is significant for the Indian perspective in the question of foreign currency earning. Due to geographical position, the period from October to March is the season for tourism in India. 
Table 3. Foreign Exchange Earnings from Tourism in India during 2015 and comparative figures of 2014 and 2013 (in US\$ billions)

\begin{tabular}{|c|c|c|c|c|c|}
\hline \multirow{2}{*}{ Month } & \multicolumn{2}{|c|}{ Foreign Exchange Earnings (in US\$ billions) } & \multicolumn{2}{c|}{ Percentage Change } \\
\cline { 2 - 6 } & $2013 \# 2$ & $2014 \# 2$ & $2015 \# 2$ & $2014 / 13$ & $2015 / 14$ \\
\hline January & 1.984 & 1.880 & 1.945 & $-5.2 \%$ & $3.5 \%$ \\
\hline February & 1.906 & 1.849 & 1.877 & $-3.0 \%$ & $1.5 \%$ \\
\hline March & 1.755 & 1.716 & 1.783 & $-2.2 \%$ & $3.9 \%$ \\
\hline April & 1.329 & 1.520 & 1.609 & $14.4 \%$ & $5.9 \%$ \\
\hline May & 1.207 & 1.337 & 1.491 & $10.8 \%$ & $11.5 \%$ \\
\hline June & 1.227 & 1.470 & 1.498 & $19.8 \%$ & $1.9 \%$ \\
\hline July & 1.442 & 1.712 & 1.884 & $18.7 \%$ & $10.0 \%$ \\
\hline August & 1.328 & 1.706 & 1.752 & $28.5 \%$ & $2.7 \%$ \\
\hline September & 1.224 & 1.488 & 1.573 & $21.6 \%$ & $5.7 \%$ \\
\hline October & 1.404 & 1.636 & 1.621 & $16.5 \%$ & $-0.9 \%$ \\
\hline November & 1.703 & 1.853 & 1.912 & $8.8 \%$ & $3.2 \%$ \\
\hline December & 1.936 & 2.069 & 2.126 & $6.9 \%$ & $2.8 \%$ \\
\hline Total & 18.445 & 20.236 & 21.071 & $9.7 \%$ & $4.1 \%$ \\
\hline
\end{tabular}

Source: The Bureau of Immigration, India \# 2 Revised Estimates.

Note: The FEEs of 2015 (both in terms \& US \$ billion) have undergone a revision due to adoption of final figure of FTAs of 2015 and adoption of Consumer Price index (CPI) (Urban) for inflating FEEs per capita.

The above table reveals that the foreign exchange earning has increased in India, though the foreign exchange earnings have not been significantly changed throughout the year but it has a positive impact on the Balance of Payments (BOP) in India.

Table 4. Total investments under different infrastructure project in India over the year

\begin{tabular}{|c|c|c|}
\hline Financial Year & Number of Projects & Total Project Cost in INR (Crore) \\
\hline 2000 & 20 & $19,651.10$ \\
\hline 2001 & 27 & $7,475.96$ \\
\hline 2002 & 22 & $6,111.52$ \\
\hline 2003 & 31 & $26,669.70$ \\
\hline 2004 & 31 & $30,858.05$ \\
\hline 2005 & 63 & $61,944.97$ \\
\hline 2006 & 92 & $58,800.66$ \\
\hline 2007 & 102 & $95,258.13$ \\
\hline 2008 & 114 & $156,216.54$ \\
\hline 2009 & 172 & $156,983.77$ \\
\hline 2010 & 201 & $120,804.29$ \\
\hline 2011 & 236 & $132,817.13$ \\
\hline 2012 & 239 & $141,994.99$ \\
\hline 2013 & 264 & $123,435.61$ \\
\hline 2014 & 488 & $207,256.15$ \\
\hline 2015 & 505 & $169,909.90$ \\
\hline
\end{tabular}

Source: https://infrastructureindia.gov.in/year-wise.

Over the year both number of project and the projected cost i.e. total investment over the year have been increased. The year which follow the double digit positive growth rate of FTAs in India or near about double digit are the year of correspondence to good investment. Only the year 2009 experienced a negative growth rate with a significant amount of investment in infrastructure.

Now we consider a time series equation: $Y_{t}=\beta_{1} X_{t}+\alpha+u_{t}$.

Where:

$-\alpha$ is the intercept. 
$-Y_{t}$ is the dependent variable (DV) i.e. FTAs where and $t=$ time.

$-X_{t}$ represents one independent variable (IV) i.e. Project cost in infrastructure investment.

$-\beta_{1}$ is the coefficient for that IV.

$-u_{t}$ is the error term.

Summer statistics

\begin{tabular}{|l|c|}
\hline Regression statistics & 0.926453 \\
\hline Multiple R & 0.858315 \\
\hline R Square & 0.848195 \\
\hline Adjusted R Square & 729087.7 \\
\hline Standard Error & 16 \\
\hline Observations & 16 \\
\hline
\end{tabular}

\begin{tabular}{|l|c|c|c|c|c|c|c|c|}
\hline & Coefficients & $\begin{array}{c}\text { Standard } \\
\text { Error }\end{array}$ & $\mathrm{t}$ Stat & P-value & $\begin{array}{c}\text { Lower } \\
95 \%\end{array}$ & Upper 95\% & $\begin{array}{c}\text { Lower } \\
95.0 \%\end{array}$ & Upper 95.0\% \\
\hline Intercept & 2408667 & 329521.3 & 7.309594 & $3.85 \mathrm{E}-06$ & 1701914 & 3115420 & 1701914 & 3115420 \\
\hline $\begin{array}{l}\mathrm{X} \text { Variable } \\
1\end{array}$ & 26.67882 & 2.896949 & 9.209281 & $2.57 \mathrm{E}-07$ & 20.46548 & 32.89215 & 20.46548 & 32.89215 \\
\hline
\end{tabular}

From the summer statistics we can see that there is positive relation between infrastructure investment and the FTAs in India. Two-tail p-values test the hypothesis that each coefficient is different from 0 . To reject this, the p-value has to be lower than $0.05(95 \%)$. But p-value is greater than one. So the variable has a significant influence on dependent variable FTAs. Again t-values test the hypothesis that each coefficient is different from 0 . To reject this, the t-value has to be higher than 1.96 (for a 95\% confidence). Hence the variable has a significant influence on our dependent variable FTAs.

\section{Conclusion}

The critical importance of the availability of quality infrastructure has been realized by all countries, including India. Within the available resources efforts are made to provide for such infrastructure for sustaining the increase in economic growth. This requires meticulous planning and policy formulations, which, in turn, require qualitative infrastructure statistics. A clear, comprehensive and unambiguous notion of what constitute infrastructure is yet to be developed at the national and international levels. The paper also finds that India is an expanding destination to the foreign tourist. The findings in this study lend support to the current policy of the government whereby significant marketing effort is being made at the international level to further promote the Indian tourism product. The authorities should also be given due credit for constantly upgrading the infrastructure base around the India. However, while not necessarily pertinent at this point in time, the tourism absorption capacity of India is likely to become a relevant issue in the not too distant future. Research on this issue as well as on the dynamic modeling in tourism should start in the very near future.

\section{References}

1. Bala, U. (1990). Tourism in India - Policy and Perspectives. Ashish Printers and Publication Pvt. Ltd., New Delhi, pp. 44-86.

2. Canning, D. and Bennathan, E. (2000). The Social Rate of Return on Infrastructure Investments. World Bank Research Project, RPO 680-89, Washington, D.C.

3. Canning, D. and Pedroni, P. (1999). Infrastructure and long run economic Growth. CAER II Discussion Paper No. 57.

4. Crouch, G. I. and Ritchie, J. R. B. (2000). The competitive destination: a sustainability perspective. Tourism Management, 21(1), 1-7.

5. Dube, R. (1995). Multiplier Effect and the Tourism Sector. The Indian Economic Journal, 42(3), 145-153.

6. Draft of 11th Five Year Plan document, Planning Commission (2006). The Government of India.

7. Foster, D. (1985). Travel and Tourism Management, Macmillan, London.

8. Gunn, C.A. (Eds.). (1988). Tourism Planning (second edition). New York: Taylor \& Francis. 
9. Inskeep, E. (1991). Tourism Planning: An Integrated and Sustainable Development Approach. New York, Van Nostrand Reinhold. Available at: https://infrastructureindia.gov.in/year-wise(2016) (accessed on 28/6/2016).

10. Khadaroo, Jameel and Seetanah, Boopen (2007). Transport infrastructure and tourism development. Annals of Tourism Research, 34(4), 1021-1032.

11. Kaul, R. N. (1985). Dynamics of Tourism: a Trilogy. Stosius Inc/Advent Books Division.

12. Mo, Howard and Havitz (1993). Testing a Tourist Role Typology. Annals of Tourism Research, 20, 319-335.

13. Prideaux, B. (2000). The Role of the Transport System in Destination Development. Tourism Management, 21, 53-63.

14. Tourism Task Force (2003). Down the track; Better Ways To Deliver Tourism's Land Transport Infrastructure. Available at: www.ttf.org.au.

15. Zysnarski, J. (2003). Partnerstwo publiczno - prywatne. Teoria i praktyka. 